\title{
Effectiveness of structured teaching programme on the knowledge and opinion of teacher trainees about learning disabilities
}

\author{
Padmavathy D. ${ }^{1}$, K. Lalitha ${ }^{2}$, Uma Hirisave ${ }^{3}$ \\ ${ }^{1}$ Staff Nurse, Department of Nursing, NIMHANS - INI, Bangalore. \\ ${ }^{2}$ Professor, Department of Nursing, NIMHANS - INI, Bangalore. \\ ${ }^{4}$ Professor, Department of Clinical Psychology, NIMHANS - INI, Bangalore. \\ E-mail - padhu_punnud7@yahoo.com
}

\begin{abstract}
The present study was designed with the aim of evaluating the effectiveness of structured teaching program on the knowledge and opinion of teacher trainees regarding learning disabilities among children. This study was carried out among 32 teacher trainees studying the Diploma in Education (D.Ed.) course. One group pre-test, post-test without control group, quasi experimental research design was adapted for the study. Instruments, socio-demographic data sheet, knowledge questionnaire on learning disabilities and opinion questionnaire on learning disabilities (prepared by the investigator) were used to assess the changes in the level of knowledge and opinion among the Teacher trainees before and after the structured teaching program. The students are exposed to five sessions of structured teaching program which included concept and definition, incidence and prevalence, causes and classification, clinical manifestations, investigations, treatment and outcome of the learning disabilities. Data collected through self report method were analyzed and processed using descriptive statistics like percentage, mean and standard deviation. Inferential statistics such as t-test, Pearson correlation and chi-square were also used. Findings revealed that, there was significant difference in the pre and post test scores on various dimensions of knowledge and opinion questionnaire $(p<0.001)$, demonstrated the effectiveness of structured teaching program.
\end{abstract}

Keywords: teaching programme, teaching, teacher trainees, learning disability.

\section{INTRODUCTION}

Learning disabilities refers to a heterogeneous group of disorders manifested by significant difficulties in the acquisition and use of listening, speaking, reading, writing, reasoning or mathematical abilities [1]. "Learning disabilities" is an unexplained difficulty a person of at least average intelligence has in acquiring basic academic skills. These skills are essential for success at school and work, and for coping with life in general [2]. As the children with learning disability find it difficult to adjust in schools, teachers are also challenged (and charged) to find ways and provide them with the very best instruction possible. The best sources of assistance and the most promising pool of resources are to be found right there in the school. General and special educators working creatively, sharing ideas and strategies and tapping related services providers and others including speech-language therapists, psychologists, and occupational therapists, implementing progress-monitoring activities and sharing responsibility for needed adjustment in instruction [3]. These are ways to ensure that students have the best 
opportunities to succeed, and these are the ways to help educators and administrators create learning communities, pooling resources and sharing expertise to the benefit of all [4].

Early identification and interventions provided appropriately will bring about plenty of changes. When parents and teachers are equipped with adequate knowledge and appropriate skills in handling these children and also their attitude of accepting the child with learning disabilities, will help the child to improve in the future [5]. To help the child with learning disabilities, it is not only the responsibility of the teachers and parents; it is the responsibility of the mental health professionals to march forward and to reach the unreached people not only in the urban community but also in the rural community where the services are in scarce. Even the education board is functioning inadequately in this area in our country [5].

Children under 15 years of age constitute $40 \%$ of the total population. The WHO had declared that as one in five children in the world have handicap, it is a 'serious obstacle to a child's development' [6]. Mental health disorders account for the $10^{\text {th }}$ leading causes of disability in the world of children aged five years and above. Prevalence rate of $20-33 \%$ of psychiatric disorders in school children has been reported in India, and among them learning disabilities constitute 1 in 10 children [7]. Boys are more likely than girls to be identified as having a learning disability. In 2004, 10 percent of boys and 6 percent of girls ages three to seventeen had a learning disability [8]. Nearly 4 million school-age children have learning disabilities, $7.7 \%$ of children have ever been told they had learning disability. Prevalence of reading disability is conservatively estimated to range between 4 percent and 10 percent in the general, school-aged population in the United States [9]. In India, prevalence estimates of learning disability ranges from $9-39 \%$ and the incidence of dyslexia in primary school children in India has been reported to be $2-18 \%$, of dysgraphia $14 \%$ and of dyscalculia $5.5 \%$ [10].

The National Joint Committee on Learning Disabilities [11] believes that comprehensive interdisciplinary education programs are necessary for the preparation of all education professionals. To serve the needs of students with learning disabilities most effectively, all teacher trainees should have preparation that includes the competencies in the area of learning disability [1]. By doing a thorough review of Teacher education, the researcher felt that after the thorough analysis of the curricula and also the question papers of the teacher education in India showed that there is only one unit on the childhood psychological problems, the teacher trainees hardly remember the utterance of the word learning disability during their course period. Hence, learning disabilities is one such area where the teachers need adequate knowledge in handling these children in classroom situation. There are many reasons in children for school failure, but a common one is a specific learning disability. Children with learning disabilities usually have a normal range of intelligence. They try very hard to follow instructions, concentrate, and "be good" at home and in school. Yet, despite this effort, he or she is not mastering school tasks and falls behind. Learning disabilities affect at least 1 in 10 schoolchildren [12]. A recent National Institutes of Health study showed that 67 percent of young students who were at risk for reading difficulties became average or above average readers after receiving help in the early grades [13].

The identification of learning disability begins when parents or teachers suspect that a student is having problem coping with everyday school tasks because it is always an educational one. The teacher's rapport with a learning disabled child is proved to be vital in helping the child succeed [14]. According to learning disabilities services, students can greatly benefit when the teacher takes a little time and thought to accommodate these needs. These students may need accommodation in some class room activities, assignments and exams. Making the child aware of a disability is a great service to the child. Unless such children are identified and properly treated, they may develop secondary emotional, social and family problems [15]. It is in this context, the teacher's role become vital in safe guarding and promoting the mental health of children and early identification of deviations from normal. The school is one of the most organized and powerful systems in the society which presents opportunity to work through it and to influence the health and wellbeing of those who come in contact with it. This is especially true in Indian setting where there is a considerable shortage in mental health facility for children. Hence the researcher felt that it is important to understand the knowledge and opinion of teacher training students towards the child's disabilities as they who would become the future teachers and therefore it is essential that they should have the knowledge regarding the learning disabilities in children. 


\section{METHODOLOGY}

\section{OBJECTIVES}

- To evaluate the effectiveness of structured teaching programme on knowledge of teacher trainees towards learning disabilities.

- To evaluate the effectiveness of structured teaching programme on opinion of teacher trainees towards learning disabilities.

\section{HYPOTHESIS}

- H1: There will be statistically significant difference between the scores obtained by the teacher trainees (study subjects) on the level of knowledge about learning disabilities prior to and after the structured teaching programme.

- H2: There will be statistically significant difference between the scores obtained by the teacher trainees (study subjects) on the level of opinion about learning disabilities prior to and after the structured teaching programme.

One group pre-test post-test quasi experimental design research design was used for the study. The population for the study was Teacher trainees. Teacher trainees who were undergoing Diploma in Education programme formed the sample for the study. Sample size was thirty two teacher trainees from second year D.Ed. programme. Census method was used as sampling technique. INCLUSION CRITERIA

- Those who are undergoing teacher training program to teach in primary schools.

- Those teacher trainees who have registered for DEd training.

- Those teacher trainees who are undergoing DEd training only in English medium. EXCLUSION CRITERIA

- Those teacher trainees who are on medical leave during the data collection period.

- Those teacher trainees who have attended refresher or orientation courses on learning disabilities. Tools for the present study were constructed by the researcher. The tool comprised of:

Section A : Sociodemographic data sheet.

Section B: Knowledge about learning disability questionnaire.

Section C: Opinion about learning disability questionnaire.

Section B - knowledge questionnaire consisted of 40 items as multiple choice questions with only one correct answer for each. The questionnaire was divided into seven dimensions like concept and definition, incidence and prevalence, causes and classification, clinical manifestations, investigations, treatment, and outcome. Each correct response carries one mark and wrong answer carries zero (0). Maximum score is 40 and minimum score is zero (0). Section $C$ - opinion questionnaire consisted of 40 items prepared in Likert type with 5-point scale as strongly agree (SA), agree (A), undecided (UD), disagree (DA) and strongly disagree (SD). The scale was divided into four dimensions as caring, punishing, accepting and rejection. Among these, items under the dimension of caring and accepting are positively worded and items under the dimensions of punishing and rejection are negatively worded. For the 27 positive items the Scoring is 5 marks for strongly agree, 4 for agree, 3 for undecided, 2 for disagree and 1 for strongly disagree. Score was reversed for the 13 negative items. Thus the total score one could obtain was $40 \times 5=200$ and the minimum score was 40 .

Self report method was used for data collection. Teacher trainees were explained about the purpose of the study and the consent to participate in the study was obtained. Pretest was administered prior to structure teaching programme. Five teaching sessions were carried out. Each session lasted for one hour with lecture cum discussion. Post test was conducted one day after the last teaching session. Systematically collected raw data were coded, computed, analyzed and processed using descriptive and inferential statistics. Data were analyzed using the SPSS 16, windows 2003 version. Descriptive statistics such as mean, standard deviation, frequency and percentage were used to analyze the socio demographic data. Pre assessment and post assessment scores were computed using paired t test Pearson's correlation and ' $t$ ' test were used to associate the socio demographic variables with knowledge and attitude scores. Association was done by using Pearson's chi square test. 
TABLE 1

ITEM WISE EFFECTIVENESS OF STRUCTURED TEACHING PROGRAMME ON THE LEVEL OF KNOWLEDGE OF TEACHER TRAINEES TOWARDS LEARNING DISABILITIES ( $\mathrm{N}=32)$

\begin{tabular}{|c|c|c|c|c|c|c|}
\hline $\begin{array}{l}\text { Item } \\
\text { No. }\end{array}$ & Knowledge questionnaire & $\begin{array}{c}\text { Pre-test } \\
\text { Correct } \\
\text { score }\end{array}$ & $\begin{array}{c}\text { Total } \\
\text { wrong } \\
\text { response }\end{array}$ & $\begin{array}{l}\text { Post -test } \\
\text { Correct score }\end{array}$ & $\begin{array}{c}\text { Total } \\
\text { wrong } \\
\text { response }\end{array}$ & Significance \\
\hline 1 & Learning disability belongs to the & 3 & 29 & 31 & 1 & $0.000^{* *}$ \\
\hline 3 & Learning disability is found in association with & 12 & 20 & 22 & 10 & $0.013^{*}$ \\
\hline 4 & Learning disability is the result of & 8 & 24 & 22 & 10 & $0.001^{* *}$ \\
\hline 5 & In INDIA, among the learning disabilities, the incidence of & 13 & 19 & 30 & 2 & $0.000^{* *}$ \\
\hline 8 & Most common type of learning disability is & 14 & 18 & 29 & 3 & $0.000^{* *}$ \\
\hline 9 & $\begin{array}{l}\text { Equal chance of developing learning disability in the other children } \\
\text { of the same family }\end{array}$ & 12 & 20 & 21 & 11 & $0.049^{*}$ \\
\hline 10 & One of the common causes for learning disability is & 5 & 27 & 29 & 3 & $0.000^{* *}$ \\
\hline 11 & Learning disability is commonly manifested in the form of & 10 & 22 & 30 & 2 & $0.000^{* *}$ \\
\hline 16 & Student with reading disorder show & 12 & 20 & 27 & 5 & $0.000^{* *}$ \\
\hline 17 & Student with reading disorder will have trouble in & 14 & 18 & 21 & 11 & $0.065^{*}$ \\
\hline 18 & Individuals with writing disorder & 9 & 23 & 20 & 12 & $0.003^{* *}$ \\
\hline 19 & Mathematical disorder includes & 17 & 15 & 24 & 8 & $0.065^{*}$ \\
\hline 20 & Trouble in relating letters with their sounds while reading is seen in & 15 & 17 & 21 & 11 & 0.146 \\
\hline 21 & $\begin{array}{l}\text { Excessive technical errors of punctuation, capitalization, grammar } \\
\text { etc are seen as manifestations in }\end{array}$ & 22 & 10 & 22 & 10 & 1.000 \\
\hline 22 & Difficulty to read time from clock is seen in & 8 & 24 & 11 & 21 & 0.453 \\
\hline 23 & Word building is used as an exercise & 7 & 25 & 18 & 14 & $0.007^{* *}$ \\
\hline 24 & Child with learning disability is recognized when & 12 & 20 & 16 & 16 & 0.424 \\
\hline 25 & Learning problem can be detected & 21 & 11 & 31 & 1 & $0.006^{* *}$ \\
\hline 26 & The first person likely to detect the learning disability in children is & 25 & 7 & 26 & 6 & 1.000 \\
\hline
\end{tabular}

Indian Journal of Mental Health 2016 ; 3(1) 


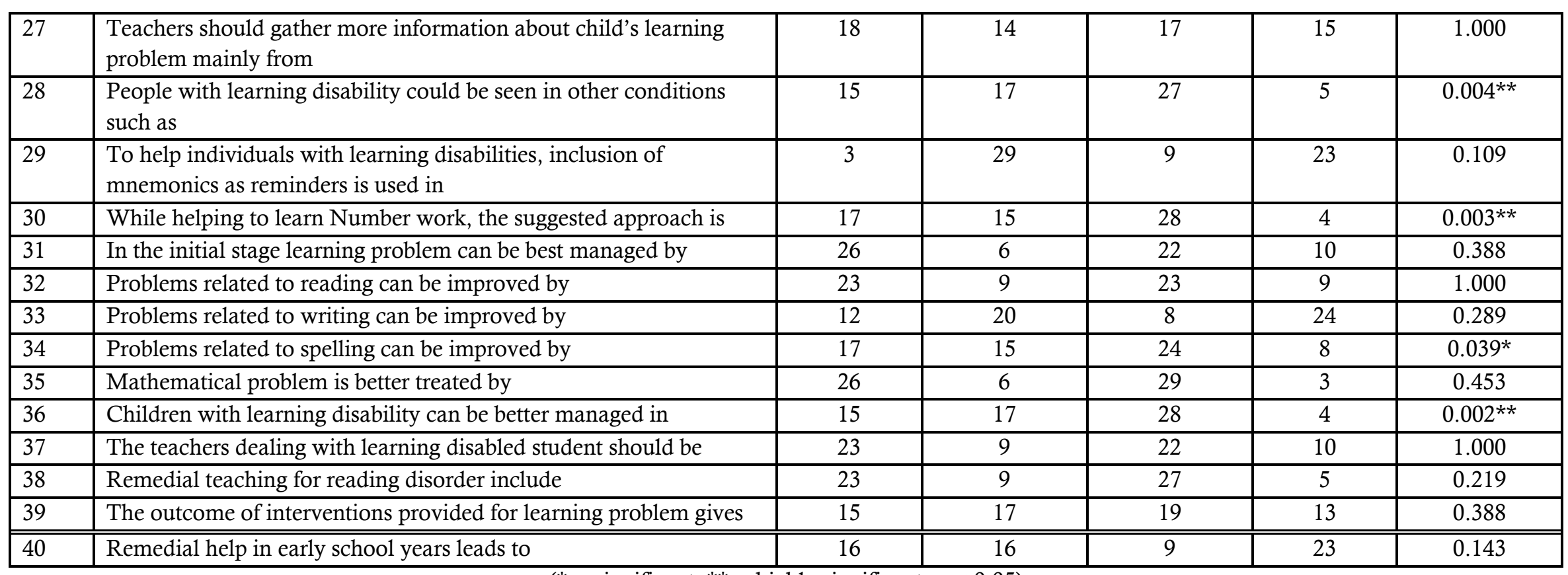

$\left(^{*}=\right.$ significant, ${ }^{* *}=$ highly significant, $\left.\mathrm{p}<0.05\right)$

The above table (Table 1) shows the item wise effectiveness of structured teaching programme on the level of knowledge of the teacher trainees towards learning disabilities. There was highly significant changes on 17 items (item no- 1,2,4,5,6,7,8,10,11,14,16,18,23,25,28,30 \& 36) indicating knowledge gain. Whereas 5 items (item no- 3, 9, 17, 19, \& 34) showed significant changes in the knowledge gain and in the rest of the items even though there was knowledge gain, but it was not statistically significant $(\mathrm{p}<0.05)$. 
TABLE 2

ITEM WISE EFFECTIVENESS OF STRUCTURED TEACHING PROGRAMME ON THE LEVEL OF OPINION OF TEACHER TRAINEES TOWARDS LEARNING DISABILITIES $(\mathrm{N}=32)$

\begin{tabular}{|c|c|c|c|c|c|c|c|c|c|c|c|c|c|}
\hline $\begin{array}{c}\text { Item } \\
\text { No }\end{array}$ & Items & $\begin{array}{l}\text { Pre } \\
\text { SA }\end{array}$ & $\begin{array}{c}\text { Post } \\
\text { SA }\end{array}$ & $\begin{array}{c}\text { Pre } \\
\text { A }\end{array}$ & $\begin{array}{c}\text { Post } \\
\text { A }\end{array}$ & $\begin{array}{l}\text { Pre } \\
\text { UD }\end{array}$ & $\begin{array}{l}\text { Post } \\
\text { UD }\end{array}$ & $\begin{array}{l}\text { Pre } \\
\text { DA }\end{array}$ & $\begin{array}{l}\text { Post } \\
\text { DA }\end{array}$ & $\begin{array}{l}\text { Pre } \\
\text { SD }\end{array}$ & $\begin{array}{c}\text { Post } \\
\text { SD }\end{array}$ & $\begin{array}{l}\text { Chi-square/ } \\
\text { McNemar }\end{array}$ & p-value \\
\hline 1 & $\begin{array}{l}\text { I will care for this child more than other student } \\
\text { in my class. }\end{array}$ & 56.3 & 71.9 & 28.1 & 25.0 & 6.3 & 3.1 & 3.1 & & 6.3 & & 5.671 & 0.684 \\
\hline 2 & $\begin{array}{l}\text { I feel that this student can spoil the reputation of } \\
\text { the school }\end{array}$ & 6.3 & & 15.6 & 6.3 & 25.0 & 21.9 & 40.6 & 15.6 & 12.5 & 56.3 & 13.597 & 0.327 \\
\hline 3 & $\begin{array}{l}\text { I feel like often consulting others (including } \\
\text { experts) on how to help the student }\end{array}$ & 34.4 & 5.0 & 40.6 & 43.8 & 12.5 & 6.3 & & & 12.5 & & 11.513 & 0.074 \\
\hline 4 & $\begin{array}{l}\text { I think that my extra attention towards the child } \\
\text { would change the child's problem }\end{array}$ & 50.0 & 71.9 & 28.1 & 25.0 & 9.4 & 3.1 & 6.3 & & 6.3 & & 6.043 & 0.642 \\
\hline 5 & $\begin{array}{l}\text { I feel that I reward the student for his } \\
\text { accomplishments }\end{array}$ & 25 & 37.5 & 31.3 & 34.4 & 15.6 & 9.4 & 18.8 & 18.8 & 9.4 & & 14.226 & 0.286 \\
\hline 6 & $\begin{array}{l}\text { I feel that I am unable to pay attention to other } \\
\text { students because of this student }\end{array}$ & 21.9 & 9.4 & 18.8 & 12.5 & 18.8 & 25.0 & 25.0 & 25.0 & 15.6 & 28.1 & 25.358 & 0.064 \\
\hline 7 & $\begin{array}{l}\text { I think that the student has to be corrected if } \\
\text { he/she does mistakes }\end{array}$ & 21.9 & 25.0 & 50.0 & 50.0 & 12.5 & 9.0 & 6.3 & & 9.4 & 15.6 & 18.662 & 0.097 \\
\hline 8 & $\begin{array}{l}\text { I think that remedial teaching will solve the } \\
\text { problem of the student }\end{array}$ & 34.4 & 53.1 & 40.6 & 46.9 & 12.5 & & 6.3 & & 6.3 & & 2.395 & 0.664 \\
\hline 9 & $\begin{array}{l}\text { I believe that child willbecome normal like other } \\
\text { children }\end{array}$ & 21.9 & 37.5 & 18.8 & 28.1 & 31.3 & 21.9 & 21.9 & 9.4 & 6.3 & 3.1 & 20.383 & 0.203 \\
\hline 10 & $\begin{array}{l}\text { I will be lenient with this student compared to } \\
\text { other students while teaching }\end{array}$ & 9.4 & 15.6 & 43.8 & 28.1 & 21.9 & 25.0 & 15.6 & 21.9 & 9.4 & 9.4 & & 0.832 \\
\hline 11 & I feel that I may punish this student frequently & 9.4 & 3.1 & 28.1 & 21.9 & 18.8 & 3.1 & 21.9 & 12.5 & 21.9 & 59.4 & 20.823 & 0.185 \\
\hline 12 & I feel that the student need constant supervision & 15.6 & 21.9 & 34.4 & 50.0 & 28.1 & 25.0 & 9.4 & 3.1 & 12.5 & & 10.675 & 0.557 \\
\hline 13 & $\begin{array}{l}\text { I think that Iam patient enough to give repeated } \\
\text { corrections to the student }\end{array}$ & 21.9 & 21.9 & 28.1 & 50.0 & 25.0 & 12.5 & 15.6 & 9.4 & 9.4 & 6.3 & 25.802 & $0.057^{*}$ \\
\hline 14 & I feel that the student's behavior annoys me & 9.4 & 3.1 & 31.3 & 21.9 & 25.0 & 31.3 & 25.0 & 28.1 & 9.4 & 15.6 & 16.323 & 0.431 \\
\hline 15 & $\begin{array}{l}\text { I feel confident that the student can be improved } \\
\text { by my additional support }\end{array}$ & 62.5 & 65.6 & 18.8 & 25.0 & 3.1 & 6.3 & 6.3 & 3.1 & 9.4 & & 13.019 & 0.368 \\
\hline 16 & $\begin{array}{c}\text { I think that I allowed this student to be free } \\
\text { when compared to other students }\end{array}$ & 28.1 & 12.5 & 37.5 & 34.4 & 15.6 & 9.4 & 9.4 & 12.5 & 9.4 & 31.3 & 21.400 & 0.374 \\
\hline
\end{tabular}

Indian Journal of Mental Health 2016 ; 3(1) 


\begin{tabular}{|c|c|c|c|c|c|c|c|c|c|c|c|c|c|}
\hline 17 & $\begin{array}{c}\text { I feel that I shall shout at the student when I get } \\
\text { annoyed }\end{array}$ & 12.5 & 6.3 & 15.6 & 12.5 & 31.3 & 15.6 & 28.1 & 37.5 & 12.5 & 28.1 & 13.880 & 0.608 \\
\hline 18 & $\begin{array}{l}\text { I feel that proper guidance will help the student } \\
\text { to improve }\end{array}$ & 62.5 & 68.8 & 12.5 & 31.3 & & & 12.5 & & 12.5 & & 2.676 & 0.444 \\
\hline 19 & $\begin{array}{l}\text { I think punishing the student for not doing well } \\
\text { can affect the student permanently }\end{array}$ & 25.0 & 28.1 & 25.0 & 12.5 & & 3.1 & 15.6 & 28.1 & 34.4 & 28.1 & 10.642 & 0.560 \\
\hline 20 & $\begin{array}{l}\text { I shall change the medium of the child if the } \\
\text { child has difficulty with English. }\end{array}$ & 21.9 & 6.3 & 28.1 & 21.9 & 21.9 & 28.1 & 9.4 & 18.8 & 18.8 & 25.0 & & $0.007^{* *}$ \\
\hline 21 & $\begin{array}{l}\text { I believe that I should cater to the needs of the } \\
\text { student with LD without grudging }\end{array}$ & 6.3 & 28.1 & 31.3 & 31.3 & 43.8 & 28.1 & 12.5 & 12.5 & 6.3 & & 16.383 & 0.174 \\
\hline 22 & $\begin{array}{l}\text { I believe in letting the child have all the } \\
\text { privileges as other children }\end{array}$ & 9.4 & 12.5 & 28.1 & 56.3 & 31.3 & 18.8 & 25.0 & 12.5 & 6.3 & & 27.220 & $0.007^{* *}$ \\
\hline 23 & $\begin{array}{l}\text { I think that future of the student rests in the } \\
\text { hands of his teacher }\end{array}$ & 40.6 & 43.8 & 37.5 & 37.5 & 6.3 & 9.4 & 6.3 & 6.3 & 9.4 & 3.1 & 15.502 & 0.488 \\
\hline 24 & I will ask the child to leave the school & 6.3 & 3.1 & 18.8 & 6.3 & 6.3 & 3.1 & 15.6 & 6.3 & 53.1 & 81.3 & 28.132 & $0.030^{*}$ \\
\hline 25 & $\begin{array}{l}\text { I feel that Iam optimistic about the student's } \\
\text { education }\end{array}$ & 15.6 & 43.8 & 31.3 & 34.4 & 31.3 & 12.5 & 12.5 & 3.1 & 9.4 & 6.3 & 12.211 & 0.729 \\
\hline 26 & $\begin{array}{l}\text { I wish I was not his teacher because he has } \\
\text { many other medical problems }\end{array}$ & 15.6 & 9.4 & 28.1 & 9.4 & 28.1 & 3.1 & 15.6 & 21.9 & 12.5 & 56.3 & 18.500 & 0.295 \\
\hline 27 & $\begin{array}{l}\text { I believe that the problem is not under the } \\
\text { student's control }\end{array}$ & 15.6 & 12.5 & 37.5 & 50.0 & 15.6 & 3.1 & 21.9 & 15.6 & 9.4 & 18.8 & 25.006 & 0.070 \\
\hline 28 & I often feel relieved when this student is absent & 25.0 & 3.1 & 18.8 & 6.3 & 25.0 & 9.4 & 21.9 & 40.6 & 9.4 & 40.6 & 23.385 & 0.104 \\
\hline 29 & $\begin{array}{l}\text { I feel it is the responsibility of the teacher to } \\
\text { involve parents in remedial teaching }\end{array}$ & 40.6 & 3.1 & 25.0 & 3.1 & 6.3 & 3.1 & 25.0 & 40.6 & 3.1 & 50.0 & 10.067 & 0.863 \\
\hline 30 & $\begin{array}{l}\text { I think that the student's differentiation is } \\
\text { incurable, hence his problems can't be solved }\end{array}$ & 21.9 & 6.3 & 18.8 & 6.3 & 28.1 & 18.8 & 18.8 & 12.5 & 12.5 & 56.3 & 11.266 & 0.793 \\
\hline 31 & $\begin{array}{l}\text { I think group therapy will help the child with } \\
\text { learning disability }\end{array}$ & 18.8 & 28.1 & 43.8 & 40.6 & 25.0 & 6.3 & 6.3 & 12.5 & 6.3 & 12.5 & & 0.839 \\
\hline 32 & I feel ashamed to say that this is my student & 9.4 & 18.8 & 21.9 & 6.3 & 15.6 & 3.1 & 25.0 & 9.4 & 28.1 & 62.5 & 13.265 & 0.653 \\
\hline 33 & $\begin{array}{l}\text { I think that immediate feedbacks will help the } \\
\text { student }\end{array}$ & 46.9 & 75.0 & 28.1 & 25.0 & 6.3 & & 3.1 & & 15.6 & & 1.659 & 0.798 \\
\hline 34 & $\begin{array}{l}\text { I feel that all the children with learning disability } \\
\text { should be sent to special school }\end{array}$ & 25.0 & 3.1 & 28.1 & 18.8 & 18.8 & 9.4 & 18.8 & 34.4 & 9.4 & 34.4 & 11.293 & 0.791 \\
\hline 35 & $\begin{array}{l}\text { I think that positive learning climate will make } \\
\text { student feel that they are capable of learning }\end{array}$ & 40.6 & 53.1 & 37.5 & 40.6 & 6.3 & 3.1 & 3.1 & 3.1 & 12.5 & & 16.421 & 0.173 \\
\hline 36 & $\begin{array}{l}\text { I feel that use of computer technology will help } \\
\text { the student with learning disability }\end{array}$ & 31.3 & 50.0 & 40.6 & 43.8 & 15.6 & 6.3 & 3.1 & & 9.4 & & 9.116 & 0.333 \\
\hline
\end{tabular}




\begin{tabular}{|c|c|c|c|c|c|c|c|c|c|c|c|c|c|}
\hline 37 & $\begin{array}{l}\text { I feel that I have to like this student as he/she is } \\
\text { now }\end{array}$ & 40.6 & 31.3 & 28.1 & 34.4 & 9.4 & 18.8 & 15.6 & 12.5 & 6.3 & 3.1 & 12.141 & 0.734 \\
\hline 38 & $\begin{array}{l}\text { I feel learning disabled student is not capable of } \\
\text { participating in extracurricular activities }\end{array}$ & 12.5 & 3.1 & 9.4 & 12.5 & 25.0 & 3.1 & 31.3 & 18.8 & 21.9 & 62.5 & 12.932 & 0.091 \\
\hline 39 & $\begin{array}{l}\text { I think that I assist the child in simple things by } \\
\text { giving one-to-one attention }\end{array}$ & 28.1 & 25.0 & 46.9 & 59.4 & 15.6 & 15.6 & 6.3 & & 3.1 & & 4.598 & 0.800 \\
\hline 40 & $\begin{array}{l}\text { I feel that it is useless to correct the student even } \\
\text { if the student commits mistakes }\end{array}$ & 6.3 & 9.4 & 15.6 & 3.1 & 9.4 & 9.4 & 37.5 & 34.4 & 31.3 & 43.8 & 16.172 & 0.441 \\
\hline
\end{tabular}

$\left(\mathrm{p}<0.005\right.$ is significant, * significant, ${ }^{* *}$ highly significant $)$

\section{RESULTS}

In Table 2 we show the item wise effectiveness of structured teaching programme on the level of opinion of the teacher trainees towards learning disabilities. 4 items $(13,20,22, \& 24)$ showed significant changes in the opinion in positive direction. Whereas, in the rest of the items even though there was changes in the opinion, but it was not statistically significant. To find out the effectiveness of structured teaching programme on the level of knowledge and opinion of teacher trainees towards learning disabilities, Chi-square and McNemar was employed for item-wise analysis. Findings indicated that significant improvement in all the dimensions of knowledge and opinion after the structured teaching programme (p value .000 for all the dimensions of knowledge and opinion).

Item wise analysis was carried out to find out the effectiveness of structured teaching programme on the level of knowledge of teacher trainees towards learning disabilities. In the knowledge questionnaire, Majority of 17 items (item no- 1, 2,4,5,6,7,8,10,11,14,16,18,23,25,28,30 \& 36) showed highly significant ( $p$ value $<0.000$ ) changes in the knowledge gain. Whereas 5 items (item no- $3,9,17,19, \& 34$ ) showed significant changes $(p<0.05$ ) in the knowledge gain. Hence, the present study proved that there were statistically highly significant scores obtained for the dimensions 1,2 , and 3 when compared to the pre-test.

This showed that the structured teaching programme was effective in increasing the knowledge of teacher trainees. Whereas, in the rest of the items even though there was changes in the knowledge, but it was not statistically significant. Item wise analysis of the effectiveness of structured teaching programme on the level of opinion of teacher trainees towards learning disabilities revealed these findings. In the opinion questionnaire, 2 items (item no- 20\&22) showed highly significant changes in opinion. Whereas 2 items (item no- 13, \& 24) showed significant changes in the opinion. Whereas, in the rest of the items even though there was changes in the opinion, but it was not statistically significant. This may be because; the teacher trainees already had favorable opinion in the pre-test. 


\section{DISCUSSION}

The findings of the present study can be compared with the study conducted in the past that examined whether participation in a 13-week undergraduate inclusive education course co varied with an improvement in the self-efficacy of preservice elementary education teachers [15]. Similarly, another research investigated the nature of concerns and attitudes held by pre-service teachers regarding inclusive education and their degree of comfort on interaction with people with disabilities [16]. This study is the first in a series of studies investigating the international training of students for eventual adoption of inclusive education. Results indicated that pre-service teachers have more positive attitudes towards people with disabilities and inclusion, and more confidence in implementing inclusive practice when they have had additional training and / or experience with people with disabilities [17].

The present study also showed that structured teaching programme was effective in changing the knowledge and opinion of teacher trainees, when the sores were compared between pre-test and post test, where Knowledge mean score improved from 17.75 to 28.78 and Opinion mean score improved from 138.9 to 159.40 , which was statistically highly significant.

There were no literature to compare the effectiveness of structured teaching programme on teachers' both knowledge and opinion together and no such study has been conducted in our Indian context, hence the discussion was limited.

The major findings in the above description of effectiveness of structured teaching programme on the level of knowledge and opinion of teacher trainees towards learning disabilities, the researcher concluded that majority of the teacher trainees had improvement in scoring on both knowledge and opinion dimensions, hence the researcher felt that such educational programmes may be very beneficial for the teachers to assist towards betterment of the children with learning disabilities and to gain enough knowledge and thus develop a positive opinion to work with children having learning disabilities.

After a thorough search made by the researcher on the studies conducted with teacher trainees, it is concluded no such study was conducted in the Indian setting. This study has helped the teacher trainees for identifying and helping the children with learning disabilities in normal school education. The study on effectiveness of structured teaching programme on the level of knowledge and opinion of teacher trainees towards learning disabilities in children was under taken since learning disabilities were recognized as a major problem in school going population in today's world. The findings of the study suggested that there was a need for giving structured teaching programme for the teacher trainees. The post test results suggested that the teaching programme was effective in changing the knowledge and opinion of teacher trainees. Future research should focus on the interventions (class room management) provided for learning disabled children. Information booklet for teachers on classroom management of children with learning disabilities was prepared as a part of the study that would pave a way for gaining knowledge and developing favorable opinion towards children with learning disabilities in a long run.

\section{REFERENCES}

1. Hammill DD, Leigh JE, McNutt G, Larsen SC. A new definition of Learning Disabilities. National Joint Committee for Learning Disabilities ; 1988.

2. Mental Health and Growing up. Fact Sheet 10: The child with general learning disability: for parents and teachers. Third edition. 2002. Retrieved from www.rcpsych.ac.uk/mentalhealthinformation/mentalhealthandgrowingup/10learningdisability.aspx.

3. Lerner JW. Learning disabilities: Theories, diagnosis, and teaching strategies. Houghton Mifflin Harcourt (HMH); 1989.

4. Delisio ER. Help for Teaching students with Learning Disabilities. Education World. October 2006. Retrieved from www.education-world.com/a_issues/chat/chat181.shtml.

5. Ziraldo L. Parent teacher relationship - Build a Positive Parent/Teacher Relationship. Learning disabilities Association of Kitchener-Waterloo : York Region ; 2008. 
6. Lyon GR. Research initiatives in learning disabilities: Contributions from scientists supported by the National Institute of Child Health and Human Development. J Child Neurol 1995;10(1):120-6.

7. Shelton D. Child Mental Health Policy. J Pediatr Nurs 2000;15:115-7.

8. Sreevani R. World Mental health Day. Mental and physical health across the lifespan. Nightingale Nursing Times. A Window for Health Action 2005;58(5):7-8.

9. National Institute of Mental Health. Learning Disabilities: Decade of Brain. NIH95-3611 ; 1998.

10. National Joint committee on learning disabilities.2006. Retrieved from www.wrongdiagnosis.com/1/learning disabilities/prevalence.htm-40k

11. Fuchs D, Mock D, Morgan PL, Young CL. Responsiveness-to-intervention: Definitions, evidence, and implications for the learning disabilities construct. Learn Disabil Res Pract 2003;18(3):157-71.

12. Rakee Krishna J. A multidimensional analysis of learning disability, Unpublished $\mathrm{PhD}$ Dissertation, National Institute of Mental Health and Neuro Sciences ; 2007.

13. Lancaster J, Bain A. The Design of Inclusive Education Courses and the Self-efficacy of Preservice Teacher Education Students. Int J Disabil Dev Educ 2007;54(2):245-56.

14. Wagner RK, Francis DJ, Morris RD. Identifying English language learners with learning disabilities: Key challenges and possible approaches. Learning Disabil Res Pract 2005;20(1):6-15.

15. Loreman T, Deppeler J, Harvey D. Inclusive education: A practical guide to supporting diversity in the classroom. Psychology Press; 2005.

16. Friend M, Bursuck WD. Including students with special needs: A practical guide for classroom teachers. Allyn \& Bacon, A Pearson Education Company: Boston MA; 2002.

17. Armstrong F, Armstrong D, Barton L. Inclusive education: policy, contexts and comparative perspectives. David Fulton Publishers; 2000.

Acknowledgements - Nil.

Source of Funding - Nil

Conflict of Interest - Nil 